\title{
Genetic disease in the Arab world
}

\author{
Will be reduced only by promoting public, professional, religious, and political debate
}

$\overline{\text { Practice } \mathrm{p} 831}]\lceil$

aemoglobin disorders, inherited metabolic diseases, neurogenetic disorders, and birth defects are common among Arab populations. ${ }^{1-3}$ The relative human and economic costs of these diseases are rising because of the decline in prevalence of infectious diseases and improved but expensive medical care available to affected people. As Al-Gazali report in this week's $B M J$, although many programmes to control genetic diseases have been adopted in Arab countries, most are poorly developed ${ }^{4-6} \mathrm{~A}$ shift in public, political, and professional attitudes is needed to establish comprehensive services.

Several factors contribute to the high prevalence of genetic disease among Arabs. Some conditions such as sickle cell anaemia are the result of the advantage that the heterozygous carrier state affords against malaria. In some countries up to two thirds of marriages are between cousins, which increases the incidence of recessive disorders. ${ }^{3}$ Couples tend to marry young and family size is usually large; children born at an advanced maternal age have an increased risk of chromosomal disorders such as Down's syndrome. ${ }^{1-3}$

For many countries, particularly the oil rich states, the slow progress in developing and implementing preventive genetic programmes is due to legal and cultural issues, not financial ones. Preimplantation genetic diagnosis is not widely available, and a ban on medical abortion prevents prenatal testing and counselling and the option to terminate affected pregnancies. ${ }^{4}$ The strategy most widely used to tackle disorders such as $\beta$ thalassaemia and sickle cell disease is mandatory premarital screening followed by counselling on the risks of genetic disease. ${ }^{4-7}$ This approach is used in Bahrain, Saudi Arabia, and Jordan. However, experience from Iran and Saudi Arabia shows that most couples choose to marry despite a high risk of inherited genetic disease in their offspring. ${ }^{4-7}$

Evidence from non-Arab Muslim countries suggests that education and public debate can fuel change. In Iran a premarital thalassaemia screening and counselling programme led to the acceptance of prenatal diagnosis and the legalisation of medical abortion. As a result the birth of affected babies was reduced by $70 \%$ within five years. ${ }^{8}$ In Tunisia, Lebanon, and Morocco therapeutic abortion is now tacitly accepted if not yet legally sanctioned.

Arab communities are patriarchal, and young couples seldom enjoy the freedom to give autonomous consent during genetic counselling. ${ }^{10}$ Counselling should therefore not only include the couple (the Western model) but also key family elders. A ruling (fatwa) of the Islamic Jurisprudence Council of the World Islamic League, passed in 1990, allows therapeutic abortion for severe malformation of the fetus before the ensoulment (at 120 days' conception). ${ }^{11}$ Despite theological differences between Shiite Muslims of Iran and Sunni Arab Muslims, the Iranian experience should encourage Arab Islamic scholars to consider extending the 1990 Fatwa to
It might then be possible to amend the law to allow selective termination of pregnancy.

School curriculums and the media should be used to improve understanding of genetic diseases among health professionals and the public. Arab geneticists and health professionals must also lobby for political support to establish and fund national programmes, ${ }^{5}{ }^{6}$ integrated with existing primary and reproductive healthcare systems. Mobilising civil society, as the experience in Iran has shown, is another effective way of persuading politicians to implement genetic services.

Debate on genetic services in the Middle East is relevant to Arab Muslims in all countries. In the United Kingdom there are more than 250000 people from the Middle East, among whom an estimated 3000 births occur each year. ${ }^{12}$ Germany, Sweden, and the Netherlands have similar populations. Healthcare professionals in the West may assume that Muslim families will not consider termination of pregnancy, but this may not be the case. Families must be offered a full explanation of the risks they face and the range of interventions available to them. ${ }^{12}$

People who have left their country of origin tend to preserve their original beliefs and cultural values. Professionals providing genetic services to young Arab Muslim couples in other countries should be aware of changing attitudes in Arab countries, and should ensure their patients are not left feeling isolated and uncertain about their options.

Riad A Bayoumi professor of clinical biochemistry

(bayoumi@squ.edu.om)

College of Medicine and Health Sciences, Sultan Qaboos University, Muscat, Sultanate of Oman

Anne Yardumian consultant in haematology

North Middlesex University Hospital, London N18 1QX

Competing interests: None declared.

1 Teebi A, Farag T, eds. Genetic disorders among Arab populations. Oxford mono-

graphs on medical genetics. No 30. New York: Oxford University Press, 1997.
Alwan A, Modell B. Community control of genetic and congenital disorders. EMRO Technical Publications 24. Geneva: World Health Organization, 1997.

3 Christianson A, Howson CP, Modell B. Global report on birth defects. The hidden toll of dying and disabled children. New York: March of Dimes Birth Defects Foundation, 2006. www.marchofdimes.com/professionals/ 871_18587.asp (accessed 12 Oct 2006).

4 Al-Gazali L, Hamamy H, Al-Arrayed S. Genetic disorders in the Arab world: magnitude and prevention strategies. BMJ 2006 doi: 10.1136/ bmj.38982.704931.AE.

5 World Health Organization. Primary health care approaches for prevention and control of congenital and genetic disorders. Geneva: WHO, 2000. http:// and control of congenital and genetic disorders. Geneva: WHO, 2000. http:/
whqlibdoc.who.int/hq/2000/WHO_HGN_WG_00.1.pdf (accessed 12 whqlibdoc.
Oct 2006)

6 Act 2006) into developing countries. Nat Rev Genet 2003;4:61-8.

7 Meyer BF. Strategies for prevention of hereditary diseases in highly consanguineous population. Ann Hum Biol 2005;32:174-9.

Samavat A, Modell B. Iranian national thalassaemia screening programme. BMI 2004:329:1134-7.

9 Raz AE, Atar M, Rodnay M, Shoham-Vardi I, Carmi R. Between acculturation and ambivalence : knowledge of genetics and attitudes towards genetic testing in a consanguineous Bedouin community towards genetic testing in a

10 Al-Gazali LI. Attitudes towards genetic counseling in the United Arab Emirates. Community Genet 2005;8:48-51.

11 Albar MA. Counseling about genetics disease: an Islamic perspective. East Med Health J 1999;5:1129-33.

12 Modell B, Darlison M. Epidemiology of haemoglobin disorders in Europe: an overview. Scand J Clin Lab Invest (in press).

doi $10.1136 /$ bmj. 39002.350405 .80 